\title{
Splitsing van ATAG Holding in twee beursgenoteerde ondernemingen
}

\author{
Ir. J.B.Th. Manschot en Prof. Dr. S.W.Douma
}

\section{Inleiding}

ATAG Holding werd op l oktober 1998 opgesplitst in twee beursgenoteerde ondernemingen: ATAG Group NV (keukenapparatuur en verwarming) en Accell Group NV (fietsen).

In dit artikel wordt ingegaan op het ontstaan van de Holding en de argumenten om deze weer op te splitsen. Een aantal verschillende splitsingsmogelijkheden komt aan de orde. Tot slot wordt de wijze van splitsen en de uitvoering hiervan besproken.

\section{Korte geschiedenis van ATAG Holding}

ATAG is opgericht op 1 oktober 1948 in Ulft in de Achterhoek. De eerste producten waren éénen tweepitsgaskomforen. De verkoop geschiedde de eerste jaren voornamelijk via de butagasdealers, die de komforen verkochten als ondersteuning van hun omzet in butagas.

Enige jaren daarna werden gasfornuizen aan het assortiment toegevoegd en in de jaren zeventig werd dit uitgebreid tot een volledig programma keukenapparatuur. Een groot deel van het brede assortiment werd rechtstreeks geleverd aan keukenspecialisten. Omdat deze afnemers in tegenstelling tot de groothandel geen voorraad hadden, werd een grote wissel getrokken op de flexibiliteit in de bedrijfsvoering en met name op de logistieke functie. Zo liep in een aantal jaren

Ir. J.B.Th. Manschot is ex-voorzitter van ATAG Holding NV.

Prof. Dr. S.W. Douma is hoogleraar bedrijfseconomie aan de Katholieke Universiteit Brabant en ex-commissaris van ATAG Holding NV. de gemiddelde ordergrootte terug van circa $f 60.000$ naar $f 1.500$ en de levertermijn van gemiddeld twee maanden naar twee weken.

Om deze ontwikkeling goed te kunnen volgen werd in eigen beheer een integraal softwaresysteem ontwikkeld dat de verschillende bedrijfsprocessen online met elkaar verbond. Dit was de voorloper van de huidige systemen voor enterprise resource planning (ERP-systemen). Deze bedrijfsvoering was voor de middelgrote bedrijven zeer geavanceerd. Het organisatiesysteem was dermate gestandaardiseerd dat het ook inzetbaar was bij andere bedrijven die evenals ATAG samengestelde producten maakten.

$\mathrm{Na}$ de recessie in 1980 waarbij de woningbouw sterk terugliep en de jaarlijkse afzet van keukenapparatuur in Nederland met $65 \%$ daalde. was er behoefte aan risicospreiding. Met behulp van een extern adviesbureau werd een aantal branches in kaart gebracht. Gekozen werd voor bedrijven (eventuele overnames) die duurzame consumentenproducten fabriceerden met vergelijkbare productietechnologie, waarbij een goede bedrijfsvoering - en met name een excellente logistieke organisatie - tot competitieve voordelen zou leiden. Verder werd gekeken naar de cycliciteit van de consumentenbestedingen.

Er ontstond een lijst met producten, zoals onder meer verlichting, (stalen)meubelen, metalen badkamerproducten, zonnebanken, sporttoestellen, fïtnessapparatuur en fietsen. Met name fietsen hadden in de voorgaande twintig jaar een zeer anticyclisch afzetpatroon vertoond met de keukenapparatuur. Verder was ook het seizoenspatroon het tegenovergestelde van keuken- en verwarmingsapparaten.

Aanvankelijk vonden de eerste overnames echter plaats binnen de bestaande productgroepen 
en is ervaring opgedaan met de implementatie van het ATAG-systeem. Tevens werd de personele organisatie volgens dit systeem opgezet. Dit waren grote veranderingen voor de medewerkers van de overgenomen bedrijven, maar het wierp zijn vruchten af.

Eind 1986 kwam de mogelijkheid Batavus over te nemen en dezelfde systematiek op een fietsenfabriek toe te passen. Ook dat werkte goed. Het bedrijf dat sterk verliesgevend was, werd. mede door de turnaround-expertise die bij ATAG aanwezig was, binnen een jaar winstgevend. Reeds twee jaar later werd Batavus door de fietsenbranche als beste leverancier van het jaar gekozen.

ATAG Holding is daarna door overnames gegroeid naar zes groepen van ondernemingen in diverse Europese landen, te weten:

de keukengroep ( 5 bedrijven);

de verwarmingsgroep ( 3 bedrijven):

de fietsengroep ( 6 bedrijven);

de verlichtingsgroep ( 2 bedrijven):

de sanitaire groep ( 2 bedrijven):

de industriële toeleveringsgroep ( 2 bedrijven).

De personele organisatie van de Holding bestond uit de directieraad, bestaande uit de groepsdirecteuren en een voorzitter. Verder was er een afdeling systeemautomatisering die voor alle groepen werkte en een beperkte financiële stat.

\section{Beleidsaanpassing}

Gezien de globaliseringsontwikkelingen binnen de branches waarin de bedrijven van ATAG Holding actief waren, was het wenselijk dat de verschillende groepen internationaal expandeerden on de toenemende internationale concurrentie het hoofd te kumnen bieden.

Ook bleek dat de gewenste schaalgrootte van de groepen zeer sterk zou gaan verschillen. Dit zou een onderling afwijkende organisatiestructuur tot gevolg hebben. Verder was de relatieve voorsprong die ATAG had op het gebied van de bedrijfsvoeringssystemen minder geworden door de opkomst van ERP-aanbieders zoals SAP en Baan.

Besloten werd de inzet van het management en de financiële middelen te concentreren op twee kernactiviteiten, te weten keukenapparatuur en verwarming (Home products Group) en fietsen
(Cycle Group). Dit is gerealiseerd door samenvoeging van de keuken- en verwarmingsgroep en door de verkoop van de verlichtingsgroep, de sanitaire groep en de industriële toeleveringsgroep.

\section{Reden van de splitsing}

Gedurende de daaropvolgende periode kwam de gedachte-uitwisseling op gang of op langere termijn de samenstelling van de Holding, bestaande uit de twee kernactiviteiten de beste structuur zou zijn voor de toekomst. In de afgelopen jaren waren beide groepen qua bedrijfsorganisatie steeds meer van elkaar gaan verschillen waardoor het voordeel van de gezamenlijke softwareontwikkeling grotendeels was vervallen. De afdeling automatisering van de Holding was dan ook gesplitst en ondergebracht bij de groepen. Daardoor was de bedrijfsmatige synergie tussen de groepen minimaal geworden.

Elk van de groepen had als beleid om een vooraanstaande positie op hun eigen gebied in Europa te verwerven. Omdat in verzadigde markten van merkartikelen autonome groei langzaam gaat en relatief duur is, hadden acquisities of allianties met branchegenoten de voorkeur

Uit gesprekken bleek dat geinteresseerden voor een samenwerking met de ene groep zich niet betrokken voelden bij de andere groep. Dit werd als nadeel ervaren. Met name ondat de lietsengroep qua omzet ongeveer de helft van de omvang van de keuken- en verwarmingsgroep had, vreesde men een te grote invloed van deze laatste.

Extern was er in de financiële wereld ook een ontwikkeling gaande. Analisten gingen zich steeds meer concentreren op specifieke bedrijfssectoren. ATAG viel in twee verschillende sectoren: de sector bouwgerelateerde ondernemingen en de sector sport en vrije tijd. Ook fondsbeheerders gingen meer sectorgericht beleggen.

$\mathrm{Na}$ grondige bestudering van de diverse aspecten is in overleg met de Raad van Commissarissen besloten de beide groepen te splitsen.

\section{Keuze van de wijze van splitsen}

Bij het splitsen van beide groepen hebben wij een aantal mogelijkheden overwogen:

1 verkoop van één of beide groepen aan een branchegenoot (sell-off); 
2 de fietsengroep wordt naar de beurs gebracht en het 'moederbedrijf' - de Home products Group - ontvangt de contanten (carve-out);

3 splitsing van de Holding in twee nieuwe beursgenoteerde ondernemingen.

Deze mogelijkheden werden afgewogen tegen het strategisch beleid van het management van de groepen, de financiële en fiscale consequenties en het belang van de bestaande aandeelhouders.

Uiteindelijk werd gekozen voor de derde mogelijkheid, het vormen van een tweede beursgenoteerde onderneming. De fietsengroep zou, onder de naam Accell Group NV, naar de beurs worden gebracht. Daarbij zouden alle andere activiteiten (keukenapparatuur en verwarming) achterblijven in de bestaande holding onder de naam ATAG Group NV. Deze vorm van splitsing paste het beste bij de langetermijnplannen van de twee groepen, waarbij de mogelijkheid van groei door overnames en andere samenwerkingsvormen een belangrijke rol heeft gespeeld. Verder werd ervan uitgegaan, gezien ervaringen met het splitsen van beursondernemingen, dat er voor aandeelhouders als gevolg van de splitsing een meerwaarde gecreëerd zou worden. Aanvulling van het eigen vermogen was niet noodzakelijk. zodat ervoor gekozen is geen extra emissie van aandelen te doen.

\section{Uitvoering van de splitsing}

Bij de splitsing zouden de bestaande aandeelhouders aandelen krijgen van de Accell Group NV. Gekozen werd voor de opzet om voor elk aandeel ATAG Holding een aandeel Accell Group uit te keren. Tegelijkertijd zou ATAG Holding NV haar naam wijzigen in ATAG Group NV. Vanaf de datum van de splitsing zouden hierdoor alle aandeelhouders voor ieder aandeel ATAG Holding dat zij bezaten een aandeel ATAG Group NV en een aandeel Accell NV verkrijgen.

Juridische splitsing van ondernemingen is door wetswijziging per 1 februari 1998 sterk vereenvoudigd omdat voor ontbinding, vereffening, oprichting en overdracht van activa en passiva één rechtshandeling volstaat. Medio 1998 zijn tevens de flankerende fiscale wettelijke aanpassingen doorgevoerd die ervoor zorgen dat de splitsing en uitkering van aandelen niet gezien worden als vervreemding. De fiscus beschouwde dit laatste tot dan toe als een belastbare uitkering.
Qua welgeving liep Nederland achter bij de ons omringende landen, zodat afsplitsingen weinig voorkwamen.

De uitvoering van een splitsing is een complex en tijdrovend proces. Er werd gekozen voor een projectorganisatie in de vorm van een stuurgroep, bestaande uit de directies van beide nieuwe ondernemingen anngevuld met een juridisch adviseur, een fiscaal adviseur, de accountant en adviseurs van de bank.

De beursintroductie werd begeleid door een team van $A B N$ AMRO.

$\mathrm{Na}$ enige maanden van voorbereiding, werd op 19 februari 1998 het voornemen tot de splitsing bekend gemaakt. De uitvoering van de effectieve splitsing verliep zonder moeilijkheden omdat reeds gedurende enige jaren een beleid van verzelfstandiging van de beide groepen was gevoerd. Zo waren er nauwelijks personele consequenties, de samenstelling van het management van de groepen bleef nagenoeg onveranderd. Ook waren er nauwelijks gevolgen voor de arbeidsvoorwaarden. Gedurende de termijn waarin het splitsingsvoorstel ter inzage lag, kwamen er van financiers, toeleveranciers en andere belangstellenden geen bezwaren.

De accountant had als taak de toewijzing van de activa en ook het eigen vermogen, de schulden en de voorzieningen objectief en zonder bevoordeling van een der partijen uit te werken. De toewijzing van de activa werd bepaald op basis van historische kostprijzen conform de externe publicatiesystematiek van de Holding en zonder rekening te houden met immateriële activa.

De voorzieningen zijn toegerekend aan de groepen waarop zij betrekking hebben en de schulden zodanig verdeeld dat de solvabiliteit van beide groepen na splitsing hetzelfde percentage zou zijn. In het geval van ATAG was dit ongeveer $30 \%$.

De gemeenschappelijke componenten, zoals latente belasting- en holdingfinanciering, werden naar rato verdeeld, hetgeen in de praktijk neerkwam op tweederde deel naar de keuken- en verwarmingsgroep en eenderde deel naar de lietsengroep.

Ondat de splitsing bestond uit de introductie van een nieuw fonds op de officiële markt van de AEX-Effectenbeurs, was intensieve begeleiding door een team van de bank noodzakelijk. Naast 
de procedurele zaken was het bekend maken en onder de aandacht brengen van het nieuwe fonds Accell Group NV van groot belang. Gekozen is voor een compleet introductieprospectus met pro forma cijfers van de afgelopen drie jaren, een roadshowprogramma, met presentaties voor analisten, vermogenshebeerders, beleggers en pers en een p.r.-campagne in de pers.

Om de achterblijvende keuken- en verwarmingsgroep (onder de nieuwe naam ATAG Group NV) in de belangstelling te houden werd een wat bescheidener companyprofile prospectus gemaakt en werden eveneens roadshows gehouden om het doel van de splitsing en het toekomstig beleid van deze groep nader toe te lichten. Het gaf ook de mogelijkheid analisten en beleggers kennis te laten maken met de nieuwe Raad van Bestuur van de ATAG Group NV.

De geplande splitsingsdatum van 1 oktober 1998 (samenvallend met het vijftigjarig bestaan van ATAG) is zonder problemen gehaald, nadat op 25 september de aandeelhouders hun goedkeuring aan het voorstel hadden gegeven.

Met de splitsing werd ook de beschermingsconstructie van certificering opgeheven. Dit is in lijn met de aanbevelingen van de commissie-Peters.

De verwachting dat met de splitsing de beurswaarde zou stijgen is tot nu toe nog niet uitgekomen. Het beurssentiment ten aanzien van lokale fondsen was het afgelopen halfjaar niet erg ondersteunend! Op wat langere termijn ligt echter een meer positieve ontwikkeling van de beurskoersen van ATAG Group NV en Accell NV in de lijn der verwachtingen.

\section{I T E R A T U U R}

Schepers, K.W.M. en M.Ch. Staal, (1998), Spin-off. Een onderzoek naar de splitsing van Nederlandse beursgenoteerde ondernemingen, Nieuwegein Van den Boom Groep. 